\title{
BANKING THE UNBANKED A PERCEIVED RECIPES FOR POVERTY ERADICATION PROGRAM: INDUCTION OF A NEW ISLAMIC MICROFINANCE MODEL IN NIGERIA
}

\author{
Olorogun, L.A ${ }^{1}$
}

\begin{abstract}
This study focuses on efforts to enhance financial inclusion program through the educational orientation development in the Nigerian Islamic finance industry. A Closed User Group (CUG) consisting of Muslims across Nigeria financial educational induction program formed the study sample. The formation of the CUG sought to establish an Islamic compliant financing model that would be effective at the grassroots level in the wake of the failure of microfinance programs to deliver the much needed poverty eradication. To this end, we developed a questionnaire and conducted a financial management induction and education workshop over a period of three days. On the third day, participants were given a questionnaire, from which the results showed that proper education and adjustment to the current available model of microfinance would bring about poverty eradication and that in terms of educational traits building of staff within a typical Islamic financial institution. Future research should look into transformation of personality vices affecting financial institutions as a whole.
\end{abstract}

Keywords: Education, JIBWIS, Financial Inclusion, Organisations, Islamic Finance

JEL Classification: F65, G2, G4, J53, J62

Received: June 28, 2017; Revised: October 17, 2017;

Accepted: January 1, 2018

1 Department of Business, Abu Dhabi Men's College, Higher Colleges of Technology, Muroor Road, Abu Dhabi, United Arab Emirates Contacts: yinluk2000@yahoo.com; lolorogun@hct.ac.ae. 


\section{INTRODUCTION}

One common goal amongst organisations (service or product) is achieving its goals and objectives. However, organisations do not exist or survive without human elements technically known as labour be it skilful or unskilful (Gamberoni, von Uexkull \& Weber 2010). The actions of employees are driven by many factors, which have been debated extensively in both psychology and economic disciplines, especially those actions related to employees' relationship with their organisation in helping the organisation realise its objectives (Salzman, 2000; Blackburn, 2006). Individuals have different instincts that subsequently determine the personality of such a person or the way the person acts or reacts to his/her environment. Thus, research on personality is an ongoing subject of interest as it directly and indirectly affects business organisations and the global economy.

Islamic financial institutions' professionals are not exempted from the above conclusion. Countries such as Malaysia, United Arab Emirate (UAE) etc. are regarded as established Islamic finance hubs. Market investigators such as Annuar (2015) reported that the industry lacks qualified and competent personnel. Hisham (2015) has however, pointed out that there is a lack of correlation between the industry's growth and it human capital. He concluded that the industry is suffering from talent inadequacies. Add to this, a lack of benchmark for quality in terms of standards of educating the future Islamic finance professionals is at the summit of the problems (Taap \& al-Awar, 2015). In Annuar's (2015) report she lamented that students graduating from institutions with specialization in Islamic finance often not qualify for the available positions in the industry. In fact as Tan (2017) reported that in the UAE the banking and finance jobs' market would be tough due to negative effects of micro and macroeconomic factors on its economy. Add to this, Berisha (2017) argues that in the wake of uncertain economic environment, key strategic direction for organizations is exploring new business models i.e. continuously responding and adapting through education, training, motivation etc. to changes as they surface.

Based on the above reports, it suffices to justify the need for continuous induction program for the Islamic finance personnel. It also illuminate on the need to restructure Islamic finance educational curriculum in the institutions. From advance Islamic finance hub such as Malaysia down to Nigeria, it is right to assume how Islamic finance's expertise would be limited or unavailable. Thus, the induction program set to build the newly 
recruited officers on Islamic financial management skills particularly on Islamic microfinance. Therefore this study aims to evaluate the successes and impacts of the financial inclusion induction program on improving newly recruited individuals' knowledge gained and shift in perception on dealing with banking institutions. The study is arranged as follows: the next section highlights, Islamic finance in Nigeria, Closed User Group (CUG), methods, analysis of results, and conclusion.

\section{LITERATURE REVIEW}

\subsection{Islamic Finance in Nigeria}

Despite being member of Organisation of Islamic Conference $(\mathrm{OIC})$ and a member of Islamic Development Bank (IDB) Islamic finance initiatives kicked up late in Nigeria. A lack of expertise (Fill 2002; Deji 2013), religious affiliations, unwillingness of politicians, and tribal sentiments are amongst factors that undermined the Islamic bank's start-up. As accounted by Olorogun (2013) and as well Mustafa and Ibrahim (2013) a fierce contention between the Muslims and Christians led the worldwide logo that is, "Islamic Finance" to be changed to "Non-Interest Financial Institutions (NIFI)" in the constitution. This posed a challenge to other religious institutions such as Christianity to provide and operate noninterest based financial system according to their religious doctrine. The Muslims view Islamic banking as a mechanism for progress, however, their Christian counterpart perceives it as a method of dominance. Eventually, Jaiz Bank was flagged in 2012 with operational model compliant with the Shari'ah (Mustafa \& Ibrahim 2013). To this moment this is only Shari'ah oriented bank in Nigeria and it has never appears in its logo/trademark.

The above narration provides several insights to the state of affairs of Islamic finance in Nigeria. There is a potential market for Islamic financial activities in Nigeria (sub-Saharan in general) if those negative views were to be cast aside. This is because those negativities undermined the development of other Islamic financial institutions such as Islamic insurance (Takaful), Islamic capital market etc. It can also be concluded that the lack of expertise is as a result of intolerance and xenophobia the industry receives among the public (Christians) and political institutions which weigh down many Nigerians to specialize in Islamic finance. This was compounded by lack of enough Islamic finance institutions available in the country. Bokoharam's insurgence placed a little premium on the Christians' anxieties. 
The Nigerian Central Bank (CBN) has tremendously encouraged Islamic financial services through various financial regulatory policies (for more see Mustafa \& Ibrahim 2013). Muslims in Nigeria are 80 Million out of national population of 152 Million according to the last national census (Mustafa \& Ibrahim 2013). Majority of the Muslims are located in the NorthEastern Nigeria where almost $80 \%$ of them have never deal with financial institutions or own a bank account. Mostly, their avoidance is based on religious claims such as avoidance of riba (usury or interest) and as well illiteracy. In fact, the CBN's efforts and encouragement of Islamic finance is to encourage banking the unbanked Nigerians. The majority of the unbanked were from the North-Eastern Nigeria. In addition, according to Mustafa and Ibrahim (2013) the CBN welcomes any initiative based on noninterest finance. This prompts the current model of Islamic microfinance which its offers another view or dimension of poverty elevation program through a grass-root based Islamic oriented microfinance.

\subsubsection{Closed User Group}

The Closed User Group (henceforth CUG) is an Information Technology (IT) platform created by EasyGIS Ltd. for mapping Mosques and members of Izalat Bid'a Wa lqamat Sunna (JIBWIS) across Nigeria. Through this platform, JIBWIS represents leadership that has agreed in principle to reposition itself in contemporary Nigeria beyond missionary activities to foster economic and financial propagation among its members. The current project was formed and detached from the JIBWIS administration. It was entitled the "Manara Development Project" and pioneered on the JIBWIS platform by EasyGIS Ltd. a consulting firm based in Kaduna State Northern Nigeria. Every JIBWIS office was requested to form and present a five-man committee as part of the "Manara Financial inclusion Project Officials". In fear of a lack of competency and fidelity (BFM personality variables) etc. a three-day financial induction program was held for the selected Manara Officials. Each state official was strictly selected according to prior set conditions. Manara officials comprise a representative of JIBWIS's Imam Committee, a representative of JIBWIS'S administrative committee, a representative of JIBWIS's First Aid Committee, a computer literate, and well-seasoned and trained managerial personnel. Add to this, is a national Manara Project seven-man committee selected from JIBWIS's national committee designated to oversee the states officials committee's projects.

The Manara project idea was prompted by the harsh realities of microfinance across the globe particularly in developing and under 
developed countries. The findings of Terberger (2003), Khan (2008), Rao (2012), Dorfleitner, and Leidl \& Priberny (2014) highlighted the need to reverse the state of affairs of the current microfinance system which has landed many in the affected countries in greater debt and has worsened poverty. This has distanced many Nigerians from engaging in conventional banking and financing. Nigerians often prefer the traditional banking and finance system such as Esusu (see Njoku 2002 for more on informal finances in Nigeria) or mutual weekly contribution amongst peers and friends.

The Manara project promotes the culture of true Islamic finance that excludes any usurious lending or interest based financing. It seeks to foster stronger brotherhood among its members where donations are modelled after the early Islamic "Baytul Mal" model. With JIBWIS's multimillion membership across towns and villages in Nigeria, the Manara Project demands professional management.

The concept of relationship in management specifically relationship marketing, was first mentioned in marketing literature around two decades ago (Berry 1983) wherein personality trait is a vital consideration. Some of the main motivators such as intense competition among organisations in the same industry and demanding customers are the reasons why labour or relationship marketing has increasingly attracted the attention of researchers and practitioners alike (Sheth \& Parvatiyar, 2002). Thus, customer loyalty is a core goal of organisations (Christopher et al. 2004). Many studies have posited that profitability of an organisation depends on the degree of customers' loyalty (Chen et al. 2002).

With this preliminary, this study evaluates the effects of induction and training programs of a Closed User Group (CUG) seeking to foster better personality traits on a new Nigerian Islamic microfinance model on personality traits. Despite existing research on personality traits on financial organisations (Kierzkowski et al. 1996; Shankar et al. 2003; Worthington \& Higgs 2003; Schaupp \& Bélanger 2005; Floh \& Treiblmaier, 2006; Duckworth, Peterson, Matthews, \& Kelly 2007; Ashtiani \& Iranmanesh 2012), the majority of such research literatures concentrated on the general western view of personality without considering specific cultural or religious variables, especially the present new model of Islamic financing. The induction program's materials were designed with the view of inculcating reputable personality traits into the participants. This is important because reports show that Nigeria has a high rate of illiteracy, especially in Northeastern Nigeria where western education is largely prohibited. After retaining the BFM variables, our model added Islamic religious values. 


\section{METHODOLOGY}

\subsection{Material}

For the purpose of this research, a questionnaire was developed in English prior to the induction program. The questionnaire uses a 5-point Likert scale with 1 "strongly agree", 2 "agree", 3 "not sure", 4 "disagree", and 5 "strongly disagree". Our initial hypothesis is that traits' anomalies can be corrected or managed by Islamic religious traits which the BIG five personality traits lack. The questionnaire consisted of 16 items designed to measure various effects of the induction and training program for the success of the Manara Project. These items were modelled partly according to literature of personality traits whilst considering the specific aim of the Manara project and the participants' backgrounds.

The questionnaire's contents were designed according to training evaluation model based on Fitz-Enz's (1994) Training Validation System (TVS) Model which measures the situation involving observation of pretraining performance of the participants which led to designing of anticipatory or future performance. It also allows the organisers to design appropriate intervention to close the gap in order to ascertain whether the training is the right solution. Likewise, it allows the evaluation of pre and post training results. Finally, it provides for looking into financial income results of the training.

\subsection{Participants}

Participants ( $N=200)$ were randomly selected from among Manara project officials from the notable Nigerian organisation, Jama'at Izalah Bid'a Wa Iqamah Sunna (henceforth, JIBWIS) who participated in the three days financial inclusion induction program. The study only covered those who participated in the 3-day program. It is worth noting that Nigeria is a hub of a wide range of languages, cultures, races, etc. hence, the author ensured that the sample studied reflects this variety in the Nigerian population. However, majority of the participants were from Northern Nigeria. The target sample in this study was 200 respondents calculated based on the following formula:

$$
S S=\frac{\left(Z^{2}\right) \times(p) \times(1-p)}{C^{2}}
$$

SS = Sample Size

Z = Z-value 
$\mathrm{P}=$ Percentage of population .

$C=$ Confidence interval

The three days induction and financial training program was held from 16-18 May 2014 at Tauba Hotel Abuja the Federal Capital Territory (FCT) of Nigeria. Of the 200 expected participants, 180 were received and registered on day one and accommodated in a hotel with all expenses covered by the Manara project. The registration procedures included demographic data collection and photos for the production of official identification cards. Day two was the main induction program consisting of a series of lectures held by officials such as inauguration, professionals on information technology (IT), aims and objectives of the Manara project, financial management orientation, human management, Islamic views on banking and finance, personality traits' test, leadership orientation, and other qualities set by Islamic philosophy on handling of transactions. On the third day, after a half-day reminder lecture, the questionnaire was administered to the participants to provide insights on the successes and failures of the program toward changing their views and thoughts on handling of financial responsibilities, funds, and human relations. Participants were given ample time to respond freely. Some participants sought further clarification on some questions they considered ambiguous or vague. This was expected considering the participants' levels of education. The language barrier might have prompted some confusion. Of the total 200 distributed questionnaires, 162 were received, and nine were dropped due to incomplete information, leaving 153 usable questionnaires.

The respondents' average age ranged from 20-60 with a mean age of 35.5 (SD =16.26). Participants were strictly male. More than half of them are self-employed (technicians), and 10\% of the respondents were civil servants. Others are unemployed graduates of polytechnics and universities in Nigeria. All respondents are married, and the majority of the participants have never dealt with any financial institution or held a bank account.

\subsection{Statistical Analysis}

A series of statistical analyses such as data reliability test, descriptive statistics, Pearson correlation and factor analysis, KMO and Barteletts test, scree plot and component matrix were performed and analysed using SPSS. 


\section{RESULT AND ANALYSIS}

\section{1 Profiles of Respondent}

The demographic data revealed that the majority of the respondents have never dealt with financial houses and have never had a savings account. The initial demographic data showed that participants are matured and have everything which would warrant dealings in funding and directing of projects because the majority were capable of speaking more than a language. Multiple language skills revealed their dealings with various sections of Nigerian society. This is a skill which is an advantage for dealing with public funds and properties. Regardless of educational background, all respondents showed that they are capable of speaking at least a foreign language (English) which is a societal norm in Nigeria. This includes the Nigerian local English.

The above results lead to the theoretical confirmation of goodness of fit for the research model. This was to unveil whether the model under investigation is capable of generating educative insights on professional traits and their impacts on Islamic financial institutions. Table 1 Model Goodness of Fit i.e. indicated that $x=$ Chi-Square Value was 1145.495 (Sig= .000).

Table 1.

Test for Model Goodness of Fit

\begin{tabular}{|llr|}
\hline & Chi-Square Value & 1145.495 \\
& Df & 134 \\
& Sig & .000 \\
Log of Determinant of & Unconstrained Matrix & -12.455 \\
Under the parallel model assumption & -3.324 \\
\hline
\end{tabular}

The model was capable of generating valuable educative insights on the needed personality improvements for Islamic finance professionals. Furthermore, the researcher tested the reliability of the data set which coefficient of Alpha $(\alpha=88$ ) which means on average the data set was a good explanatory for measuring success of the financial induction program aimed in transformation of the participants philosophy.

The descriptive statistics' results indicated that the majority of the participants found the orientation organisation was satisfactory with $94.1 \%$ having agreed and strongly agreed (Mean= $1.647 \mathrm{Std} .=.59$ ). On whether the program was educational, all respondents agreed and strongly agreed (Mean=1.6667 Std. $=.47$ ) that the program enlightened tem and changed their perspectives on financial planning, particularly Islamic 
methods of financial planning. When asked about the relevance of the program to the current state of Islamic financial institutions in Nigeria, almost all the respondents $96.1 \%$ agreed and strongly agreed (Mean=1.5882 Std. $=.63$ ) indication that the induction program has the potential to resolve outstanding issues on Islamic finance in Nigeria. Respondents were asked whether the program was useless and/or unproductive, total rejections to these items were $91.6 \%$ (Mean $=4.5884$ Std. $=.77)$ and $94.1 \%($ Mean $=4.6275 \mathrm{Std} .=.79)$ respectively. When probed as to the suitability of the venue for the program, $84 \%$ (Mean $=4.1800$ $\mathrm{Std} .=1.017)$ of the respondents disagreed and strongly disagreed that the location of the program was not conducive. When asked about the strenuous duration (i.e. 3 days) of the program, 63.3\% (Mean= 3.6200 $S t d .=1.486)$ disagreed and strongly disagreed that the three days program was unbearable. The first, second, and third presentations and discussions were rated by the participants as 98\% (Mean=1.5600 Std. $=.60$ ) $62 \%$ $($ Mean $=3.6458 \mathrm{Std} .=1.237) 96.1 \% \quad($ Mean $=4.1224 \mathrm{Std}=1.0847)$ respectively. Altogether, the program was effective and achieved its objectives.

To further affirm the above results, we performed inter-item correlation matrix and Analysis of Variance to view the level of variance in the data set and variables. Table 2 and 3 depict the relationships between the measured variables. We notice a mild or average relationship among the variables with the majority having relatively low correlations.

Table 2.

Inter-Item Correlation Matrix of Perspectives on the Financial Inclusion Induction Program

\begin{tabular}{|c|c|c|c|c|c|c|c|}
\hline Variables & $\begin{array}{c}\text { Orient } \\
\text { Organisa } \\
\text { tion }\end{array}$ & Educative & $\begin{array}{c}\text { Relevan } \\
\text { ce }\end{array}$ & Useless & $\begin{array}{c}\text { Non- } \\
\text { Beneficial }\end{array}$ & Location & Strenuous \\
\hline $\begin{array}{l}\text { Orient } \\
\text { Organisation }\end{array}$ & & & & & & & \\
\hline Educative & .296 & & & & & & \\
\hline Relevance & .290 & -.190 & & & & & \\
\hline Variables & $\begin{array}{c}\text { Orient } \\
\text { Organisa } \\
\text { tion }\end{array}$ & Educative & $\begin{array}{c}\text { Relevan } \\
\text { ce }\end{array}$ & Useless & $\begin{array}{c}\text { Non- } \\
\text { Beneficial }\end{array}$ & Location & Strenuous \\
\hline Useless & .211 & -.038 & .243 & & & & \\
\hline $\begin{array}{l}\text { Non- } \\
\text { Beneficial }\end{array}$ & -.022 & -.037 & .150 & .765 & & & \\
\hline Location & .013 & .200 & -.056 & .425 & .358 & & \\
\hline Strenuous & .173 & .122 & .021 & .380 & .313 & .593 & \\
\hline Speakers & .171 & .123 & .329 & -.065 & .193 & -.125 & .021 \\
\hline First Speaker & .053 & .136 & .108 & .056 & .143 & .094 & .312 \\
\hline
\end{tabular}




\begin{tabular}{|c|c|c|c|c|c|c|c|}
\hline $\begin{array}{l}\text { First Sp. } \\
\text { Clarity }\end{array}$ & -.222 & .038 & -.069 & .210 & .338 & .398 & .336 \\
\hline $\begin{array}{l}\text { Second } \\
\text { Speaker }\end{array}$ & .379 & .095 & .100 & .175 & .126 & .310 & .306 \\
\hline Boring & -.054 & -.076 & -.166 & -.004 & .172 & .208 & .177 \\
\hline $\begin{array}{l}\text { Third } \\
\text { Speaker }\end{array}$ & .049 & -.132 & .113 & .416 & .505 & .404 & .309 \\
\hline Long Time & .131 & .007 & .292 & .304 & .074 & .060 & .170 \\
\hline Usefulness & .384 & -.095 & .362 & .139 & -.017 & -.039 & .185 \\
\hline $\begin{array}{l}\text { Objectives } \\
\text { Achiev }\end{array}$ & .137 & .150 & .267 & .136 & .341 & .225 & .200 \\
\hline
\end{tabular}

Table 3.

Inter-Item Correlation Matrix of Perspectives on the Financial Inclusion Induction Program

\begin{tabular}{|c|c|c|c|c|c|c|c|c|}
\hline Variables & Speakers & $\begin{array}{c}\text { First } \\
\text { Speaker }\end{array}$ & $\begin{array}{l}\text { First Sp. } \\
\text { Clarity }\end{array}$ & $\begin{array}{l}\text { Second } \\
\text { Speaker }\end{array}$ & Boring & $\begin{array}{c}\text { Third } \\
\text { Speaker }\end{array}$ & $\begin{array}{l}\text { Long } \\
\text { Time } \\
\end{array}$ & Usefulness \\
\hline \multicolumn{9}{|l|}{$\begin{array}{l}\text { Orient } \\
\text { Organisation }\end{array}$} \\
\hline \multicolumn{9}{|l|}{ Educative } \\
\hline \multicolumn{9}{|l|}{ Relevance } \\
\hline \multicolumn{9}{|l|}{ Useless } \\
\hline \multicolumn{9}{|l|}{ Non-Beneficial } \\
\hline \multicolumn{9}{|l|}{ Location } \\
\hline \multicolumn{9}{|l|}{ Strenuous } \\
\hline \multicolumn{9}{|l|}{ Speakers } \\
\hline First Speaker & .340 & & & & & & & \\
\hline $\begin{array}{l}\text { First Sp. } \\
\text { Clarity }\end{array}$ & .107 & .272 & & & & & & \\
\hline $\begin{array}{l}\text { Second } \\
\text { Speaker }\end{array}$ & .100 & -.112 & .082 & & & & & \\
\hline Boring & .141 & -.047 & -.103 & .252 & & & & \\
\hline Third Speaker & .079 & .092 & .326 & .560 & .226 & & & \\
\hline Long Time & -.116 & -.085 & .062 & .429 & -.098 & .261 & & \\
\hline Usefulness & .213 & .192 & -.216 & .166 & .183 & .052 & .146 & \\
\hline $\begin{array}{l}\text { Objectives } \\
\text { Achiev }\end{array}$ & .472 & .204 & .218 & .088 & -.015 & .180 & -.113 & .139 \\
\hline
\end{tabular}


Based on these results, the researcher conducted Levene's test for Heteroscedasticity. The Levene's test result was significant which means there is no homogeneity of variance (homoscedaticity) in the sample population. Thus, an exploratory principal component factor analysis was conducted to reduce and regroup the factors in order to determine the extent of variability among variables. The use of factor analysis is beyond psychology and its related fields (Steven 2002). Previous literature such as Cattell (1966a) used 16 personality factors for requiting purposes in the industry and in religious groups. Similarly, Field (2009) posited that economics may use factor analysis to verify whether productivity, profits, and workforce can be reduced to an underlying dimension of growth. Therefore, factor analysis is relevant to this current study on financial inclusion induction for personality traits development.

To test the sampling adequacy, Kaiser-Meyer-Olkin (KMO) and Bartlett's Test was conducted. Previous literature showed that the KMO and Bartlett's Test can be used to measure the strength of the relationship among variables. It is further posited that sampling adequacy in this case should be greater than 0.5 for at least a satisfactory factor analysis. Kaiser (1974) recommended 0.5 as the minimum value for acceptance, however values between 0.7 and 0.8 are acceptable and values above 0.9 are excellent. The KMO data adequacy test in the Table 4 below is .57 which is above the 0.5 recommended minimum. This means that the data is adequate and qualified to be used for factor analysis. Similarly, the Bartlett's Test probed as to whether the correlation matrix is an identity matrix was significant at 0.000 which means its associated probability is less than 0.05 . Thus, we reject the null hypothesis " $\mathrm{HO}$ " that the correlation matrix is an identity matrix. This means that we accept the alternative hypothesis " $\mathrm{H} 1$ " that the correlation matrix is not an identity matrix.

Table 4.

KMO and Bartlett's Test of Perspectives on Financial Inclusion Induction Program

\begin{tabular}{lcr}
\hline Kaiser-Meyer-Olkin Measure of Sampling Adequacy. & .577 \\
\hline \multirow{3}{*}{ Bartlett's Test of Sphericity } & Approx. Chi-Square & 1428.663 \\
& Df & 120 \\
& Sig. & .000 \\
\cline { 2 - 3 }
\end{tabular}

To establish total variance in the data set, the Eigenvalue which is the standardized variance associated with a particular factor extracted seven factors showing that seven factors contributed to the analysis (Kaiser 1974; Stevens 2000). Table 5 below shows the percent of variance 
attributed to each factor, and the cumulative variance of the factors and the previous factors. The first factor accounts for $23.99 \%$ of the variance, the second $12.80 \%$, the third $11.01 \%$, the fourth $8.62 \%$, the fifth $8.19 \%$, the sixth $7.08 \%$, and the seventh $6.55 \%$. All other factors are not significant in the analysis. According to the rule of thumb (Kaiser 1974), factors with Eigenvalues less than 1 are not qualified for further analysis. In this study, the seven stated factors with Eigenvalues are higher than, and are thus qualified for further analysis.

Table 5 .

Total Variance Explained of Perspectives on Financial Inclusion Induction Program

\begin{tabular}{|c|c|c|c|c|c|c|}
\hline \multirow[b]{2}{*}{ Component } & \multicolumn{3}{|c|}{ Initial Eigenvalues } & \multicolumn{3}{|c|}{ Extraction Sums of Squared Loadings } \\
\hline & Total & $\begin{array}{c}\% \text { of } \\
\text { Variance }\end{array}$ & Cumulative \% & Total & $\begin{array}{c}\% \text { of } \\
\text { Variance }\end{array}$ & $\begin{array}{c}\text { Cumulative } \\
\%\end{array}$ \\
\hline 1 & 3.838 & 23.990 & 23.990 & 3.838 & 23.990 & 23.990 \\
\hline 2 & 2.048 & 12.800 & 36.790 & 2.048 & 12.800 & 36.790 \\
\hline 3 & 1.763 & 11.018 & 47.808 & 1.763 & 11.018 & 47.808 \\
\hline 4 & 1.379 & 8.620 & 56.427 & 1.379 & 8.620 & 56.427 \\
\hline 5 & 1.310 & 8.190 & 64.618 & 1.310 & 8.190 & 64.618 \\
\hline 6 & 1.133 & 7.081 & 71.698 & 1.133 & 7.081 & 71.698 \\
\hline 7 & 1.049 & 6.554 & 78.252 & 1.049 & 6.554 & 78.252 \\
\hline 8 & .682 & 4.261 & 82.514 & & & \\
\hline 9 & .603 & 3.768 & 86.282 & & & \\
\hline 10 & .497 & 3.106 & 89.388 & & & \\
\hline 11 & .465 & 2.906 & 92.294 & & & \\
\hline 12 & .420 & 2.627 & 94.921 & & & \\
\hline 13 & .287 & 1.794 & 96.715 & & & \\
\hline 14 & .264 & 1.650 & 98.364 & & & \\
\hline 15 & .168 & 1.048 & 99.413 & & & \\
\hline 16 & .094 & .587 & 100.000 & & & \\
\hline
\end{tabular}

The scree plot Fig. 1 below shows the Eigenvalues against all the factors. This figure is useful in determining the number of factors to be retained. It is important to note that the curve started to flatten between factors 7 and 8 . It is equally vital to notice that factor 8 has an eigenvalue of less than 1, thus only seven factors have been retained. Cattell (1966b) argued that the sum of the Eigenvalues must not exceed the number of items in the analysis because each item adds one to the sum of variances. 


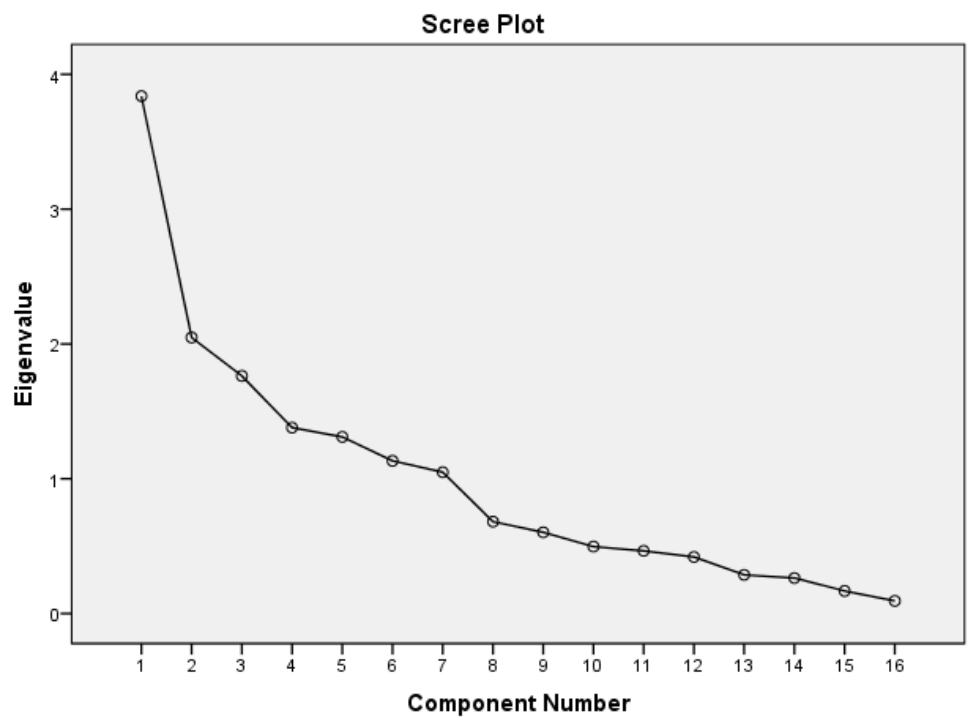

Analysis weighted by Educativeness

Figure 1.

Perspectives on Financial Inclusion Induction Program

For the sake of brevity and easy interpretation, the researcher chose to present the rotation matrix because the idea of factor analysis is to reduce the number of factors for analysis. Similarly, the idea of rotation is to reduce the number of factors to which the variables under study have higher loadings. Looking at Table 6 below, it is clear that useless, nonbeneficial, and location are substantially loaded on Factor "Component" 1, while second speaker, long time, and third speaker substantially loaded onto factor 2; usefulness and orientation organisation loaded onto factor 3; speakers and objectives achieved loaded on factor 4; first speaker, strenuous, first speaker clarity loaded on factor 5; boring and relevance loaded on factor 6 and education loaded on factor 7 .

Table 6.

Rotated Component Matrixa of Perspectives on Financial Inclusion Induction Program

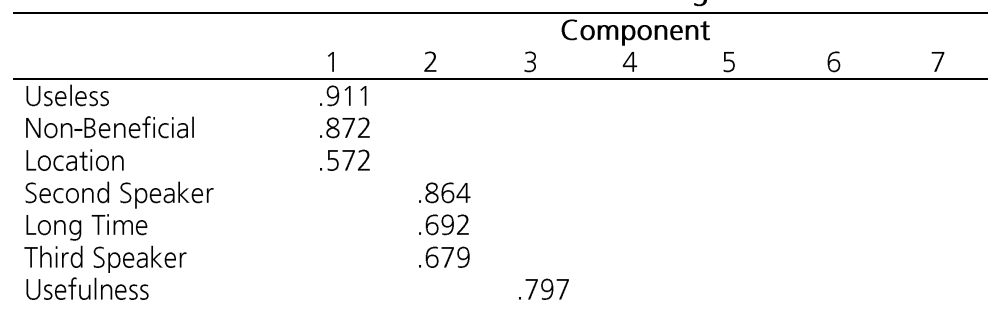




\begin{tabular}{|c|c|c|c|c|c|c|c|}
\hline & \multicolumn{7}{|c|}{ Component } \\
\hline & 1 & 2 & 3 & 4 & 5 & 6 & 7 \\
\hline Orient Organisation & & & .78 & & & & \\
\hline Speakers & & & & .85 & & & \\
\hline Objectives Achieved & & & & .80 & & & \\
\hline First Speaker & & & & & .826 & & \\
\hline Strenuous & & & & & .614 & & \\
\hline First Sp. Clarity & & & & & .559 & & \\
\hline Boring & & & & & & .859 & \\
\hline Relevance & & & & & & -.551 & \\
\hline Education & & & & & & & .901 \\
\hline
\end{tabular}

While components' rotation has no impact on the results of the component matrix, factors to be included into the analysis should be at least.50 (Kaiser 1970; 1974). Therefore, the research retains factors that are \pm .50 and above for further analysis. On a close observation, questions loaded highly on factor 1 seem to all relate to contributions of the program to the participants' education in terms of finance. Therefore, factor 1 can be labelled as Adult education. The questions loaded highly on factor 2 all appear related to whether the facilitators of the program (those who delivered lectures) are efficient in their lectures. Therefore, factor 2 can be labelled as efficient facilitators. The questions that loaded highly onto factor 3 all appear related to the level of usefulness of the program to the respondents. Therefore, factor 3 can be labelled as outcomes of education. The questions that loaded onto factor 4 all appear related to whether the speakers and objectives match well, thus factor 4 can be labelled as program effectiveness. Similarly, the questions that loaded onto factor 5 all appear related to whether the curriculum of the program was burdensome in terms of duration, thus factor 5 can be labelled as cost effectiveness. Likewise, the questions that loaded onto factor 6 all appear related to whether the program is boring and tiresome, thus factor 4 can be labelled as program evaluation. Finally, the questions that loaded onto factor 7 all appear related to whether the program was educational, thus factor 7 can be labelled as Training.

\subsection{Discussion}

The results of this study offer useful insights regarding the need for additional models of Islamic microfinance systems. Our analysis of the Manara financial project which involved grassroots members of numerous Nigeria communities, we discovered that educational background might 
have no serious effect on the personnel. Our results showed that the induction program could serve as one remedy for illiteracy in Nigeria. This may be true for other Sub-Saharan African countries.

Therefore, it suggests that for Islamic finance to be successful in Nigeria there must be educational or literacy transformation of the grassroots. Since literacy as discussed by previous literature entails both hereditary and experience, training and induction programs would serve as one its natures. The experience itself should focus on management with emphasis on finance and particularly Islamic finance. There is urgent need to capitalise on instilling the BIG FIVE variables and as well Islamic orientation into the aspiring and future Islamic finance professionals. Recruitment should not be based on educational qualification. However, proper criterial should be adopted for selection of the zealous participants.

However, such a program must be well arranged. This is evidenced in our results where program location served as one of the motivational factors for the participants. Providing accommodation encouraged participants to postpone other responsibilities and participate in the threeday program. In addition, facilitators play a pivotal role as the participants found the program interesting, stimulating, and motivational which empowered them with new skills and prepared them for future leadership roles beyond the Manara project. In light of this, factors such as "educational" stood out as a superb factor contributing to the success of the model. The induction program achieved its objective of educating the laymen on engaging with mini financial institution at the basic level.

Implications of this program in upgrading and standardisation of educational curriculum in Nigeria is beyond exaggeration because even educated participants were convinced that their views on financial systems were transformed from negative to positive. This highlights the need for including this type of financial management orientation program into the Nigerian educational system, at least at the senior secondary school level given that on average $60-70 \%$ of the senior secondary school leavers would not make it to tertiary institutions due to financial constraints and other reasons. Even in Malaysia where there are number of experts in Islamic finance, reports and complaints of Hisham (2015), Annuar (2015) and as well Taap and al-Awar (2015) in the Islamic Finance News' Magazine indicated the utmost important of upgrading our educational systems. The sample group also agreed that this induction program was timely in the wake of increasing poverty in Nigeria. One of their conclusions was such a vital program such as the Manara project should be open to all communities and beyond JIBWIS'S CUG. By this, it is posited that communities can be 
regrouped according to our CUG ideology. This would bring people with like minds together as well as their inclusion in leadership and problem solving programs. Eventually, more induction programs would be needed and Nigerian communities would be educated in the same way the participants have benefited.

Policy wise, the Nigerian government needs to look beyond common forms of microfinance and develop financial inclusion at the grassroots where members of communities would be the managers of the microfinance institutions based on CUG cooperation. Current financial inclusion's program segregate between the financial institutions which are basically conventional oriented and thus prioritise profit over community service. Advancing interest based loans to businessmen is the only mechanism adopted by these financial institutions. While the majority of Nigerian businesses are small scale in nature and require stable infrastructures for steady growth and developments. However, Nigerians are overwhelmed by lack of infrastructure such as electricity, roads etc. making it extremely difficult for their survival.

Whereas repayment of loans with interests is an obligatory responsibility, inability to honour the contract at the appropriate time would lead to confiscation of property or the entire business venture and perhaps jail. Many Nigerians fear losing their collateral in an uncertain business environment like Nigeria.

The funds under the Manara project were generated and managed by the community members and overseen by appointed officials. These results were similar to Khan's (2008) proposed microfinance model for Pakistan. Khan argued that the only way to manage rampart microfinance failures is the inclusion of charity into microfinance programs. This is the major operandi for the Manara project where members' "rich/affluent, average and poor" contributions are regarded as charity. The usage of these funds is a collective project such as for community hospitals, and consumer food chain stores selling various local raw foods at a discounted rate for registered members etc. it would surely serve as an antidote to Tan's (2017) concerns about shrinking jobs markets particularly in banking and finance profession.

Similarly, it embraces Berisha's (2017) opinions of continues development, creation of attainable new business models, education and training as antidotes to uncertainties facing the financial markets across the globe. Thus, current program also includes individual funding of feasible projects for technicians and traders. These groups form the majority of all communities in Nigeria. The individual beneficiaries would pay back their 
loans through the donation process as charity without interest. These projects have immediate effects on members of the communities particularly for the Manara members. Funds are advanced for projects without interest and members donate funds without seeking profit on investments. Further, this inclusion of the grassroots members into financial development project would boost the Nigerian Central Bank's efforts in implementing the World Bank's financial inclusion and poverty eradication programs.

The results further showed that educational background was not a barrier to the recruitments of officials. The induction program's manual and materials were prepared in English, however the discussions and presentations were in the local language, particularly Hausa. Participants indicated that repeating the program is important for the success of Islamic finance, particularly microfinance programs. Another cogent observation was that the Manara manual was distributed to the participants as a guide for the operation of the officers involved and was well accepted by the participants.

Thus, orientation and re-orientation programs would be ideal activities for the Nigerian Islamic financial industry. Lack of both human and other resources is one of the major concerns facing Islamic finance in Nigeria. The majority of the market players are unclear about Islamic injunctions on contemporary Islamic commercial contracts. Front-liners are mainly conventional oriented with a limited number of qualified Shari'ah scholars. This led to qualified scholars serving multiple competing financial institutions. Islamic financial institutions particularly in Nigeria currently mobilised funds to focus on an undefined microfinance lending with returns almost similar to the conventional microfinance (kindly see Khan 2008). However, the Manara project's mobilisation of funds would be through donations. This is similar to the early Islamic "Baytul al-Mal" funds mobilisation. These funds are thereafter returned to the society and community for the betterment of both the rich and poor.

Trustworthiness would be achieved without extra expenses because the custodians are the donator of the funds. Participants were reminded of the consequences of failure of the Manara project to Islam and Muslims in general. Thus, the success of Manara or Islamic financial institutions depends on the honesty of the professionals. Officials are committed to achieving the goals of the project with little consideration for remuneration. This was because they realised the importance of community services through the discussions on Islamic ethics, the Qur'an, and Prophetic traditions on helping one another in piety and goodness. Speakers at the 
orientation should be experienced professionals in both Islamic and conventional finance. This will eradicate the current gaps in the Islamic financial industry where the Muslim scholars have no or little knowledge of conventional finance. Bridging the gap would extend to the conventional finance background professionals with little or no knowledge of Islamic jurisprudence. The Manara orientation and induction program benefited from those professionals with both Islamic and conventional qualifications. In addition, local trainers are preferable to foreign trainers or professionals. Brevity and accuracy are fundamental qualities of such trainers including knowing the demographic backgrounds of their trainees.

The results further confirmed that financial management and operation with embedded psychological discipline is a vital tool in changing perceptions and obsolete thought on finance and financial institutions among local Nigerians (the grassroots members of the societies). When presented with a brain-storming project on investment on an island, participants' views shifted and broadened.

\section{CONCLUSION}

Islamic finance in general could benefit from this current arrangement. The system targeted and grouped members of the society according to their affiliations. Therefore, people with a similar ideology could arrange financing and financial activities that benefits them. As evidenced, microfinance has proved insufficient in eradication of poverty particularly from the grassroots viewpoint. If governments around the world specifically Muslim nations are to remove themselves form abject poverty, there must be an alternative in which grassroots financing aids are arranged or organised. Limitation to this study was that it focused on specific Islamic organisation and particularly in Nigeria context. Future research should consider larger sample at global level. 


\section{REFERENCES}

Aghalino, S. O. (2002). Trade Currencies in Pre-Colonial Nigeria. In O. N. Njoku (Eds.), Pre-Colonial Economic History of Nigeria. Retrieved August 16 , 2013.

https://www.unilorin.edu.ng/publications/aghalinoso/Aghalino\%20

TRADE\%20CURRENCIES\%20IN\%20PRECOLONIAL \%20NIGERIA.pdf.

Allport, G. W. (1943). The Psychology of Participation, Psychological Review, 52(1).

Alkahtani, A. H., Abu-Jarad, I., Sulaiman, M., Nikbin, D. (2011). The Impact of Personality and Leadership Styles on Leading Change Capability of Malaysian Managers. Australian Journal of Business and Management Research, 1(2), 70-99.

Al-Raisi, A., Amin, S. \& Tahir, S. (2011). Evaluation of e-performance Analysis and Assessment in the United Arab Emirates (UAE) Organisations. Journal of Internet and Information System, 2(2), 20 $-27$

Annuar, N. (2015). Human Capital: What does the Industry really need? Islamic Finance News, 1(1), 1-3.

Ashtiani, P. G. \& Iranmanesh, A. (2012). New approach to study of factors affecting adoption of electronic banking services with emphasis on the role of positive word of mouth. African Journal of Business Management, 6(11), 4328-4335.

Awadh, A. M. \& Wan Ismail, W. (2012). The Impact of Personality Traits and Employee Work-Related Attitudes on Employee Performance with the Moderating Effect of Organisational Culture: The Case of Saudi Arabia. Asian Journal of Business and Management Sciences, 1(10), 108-127

Barrick, M. R. \& Mount, M. K. (1993). Autonomy as a moderator of the relationships between the Big Five personality dimensions and job performance. Journal of Applied Psychology, 78, 111-118.

Balay, R. (2000). Administrators' and Teachers' Organisational Commitment. Turkey, Ankara: Nobel Publishing.

Berisha, E. (2017). Human resources must transform to meet future industry needs. IFN Education, 3(2), 3-4. Retrieved 2nd April, 2017, www.IFNEducation.com

Blackburn D. (2006). The Role, Impact and Future of Labour Law. In Labour Law: Its role, trends and potential. Labour Education 2-3, 143-144. 
Bramley, P. (1996). Evaluating training effectiveness. Maidenhead: McGraw -Hill

Buckley, R. \& Capel, J. (2009). The Theory and Practice of Training, (6th Eds.). U.S.A, Philadelphia: Kogan Page.

Bushnell, D. S. (March, 1990). Input, process, output: A Model for Evaluating Training. Training and Development Journal, 44(3), 4143.

Carnevale, A. P., \& Schulz, E.R. (July, 1990). Return on investment: Accounting for training. Training and Development Journal, 44(7), $1-32$.

Cattell, R. B. (1966a). The Scientific Analysis of Personality. Chicago: Aldine.

Cattell, R. B. (1966b). The Scree Test for the Number of Factors. Multivariate Behavioral Research, 1, 245-276.

Chen, P.-Y., \& Hitt, L.M. (2002). Measuring Switching Costs and the Determinants of Customer Retention in Internet-Enabled Businesses: A Study of the Online Brokerage Industry, Information Systems Research, 13(3), 255-274.

Chen, Mei-Liang, Tsai, Juin-Ming, \& Chen, Kuang-Jung (2009) .The Effects of Personality Traits and Conflict Management on Organisational Commitment - A Case Study of Taiwan Financial Services Personnel. The Journal of International Management Studies, 4(1), 20-29.

Christopher, M., Payne, A., \& Ballantyne, D. (2004). Relationship Marketing - Creating Stakeholder Value. Oxford: Elsevier ButterworthHeinemann.

Costa, P. T., \& McCrae, R. R. (1989). Reinterpreting the Myers-Briggs Type Indicator from the Perspective of the Five-Factor Model of Personality. Journal of Personality, 57, pp.17-40.

Deji, S. M. (2013). Feasibility of Introducing Islamic Banking in Nigeria. In K.I. Dandago, A.D. Muhammad, U.A. Oseni (Eds.) Essentials of Islamic Banking and Finance in Nigeria. Nigeria, Kano: Benchmark Publishers Limited.

Digman, J. M. (1990). Personality structure: Emergence of the Five-Factor Model, Annual Review of Psychology, 41(1), 417-440.

Dorfleitner, G., Leidl, M. \& Priberny, C. (2014). Explaining Failures of Microfinance Institutions. Working paper, Social Science Research Network: SSRN. Retrieved 22nd August 22, 2014. http://papers.ssrn.com/sol3/papers.cfm?abstract_id=2316680

Duckworth, A. L., Peterson, C., Matthews, M. D. \& Kelly, D. R. (2007). Personality Processes and Individual Differences Grit: Perseverance 
and Passion for Long-Term Goals. Journal of Personality and Social Psychology, 92(6), 1087-1101.

Erdheim, J., Wang, M., \& Zickar, M. J. (2006). Linking the Big Five Personality Constructs to Organisational Commitment. Personality and Individual Differences, 41(5), 959-70.

Eseryel, D. (2002). Approaches to Evaluation of Training: Theory \& Practice. Educational Technology \& Society 5(2), 93-98.

Field, A. (2009). Discovering Statistics Using SPSS (and sex and drugs and rock ' $n$ ' roll). In Andy Field (Third edition) "Discovering Statistics Using SPSS". U.S, Washington DC: Sage.

Fitz-Enz, J. (July, 1994). Yes...you can weigh training's value. Training, 31(7), 54-58.

Floh, A. \& Treiblmaier, H. (2006). What Keeps the E-Banking Customer Loyal? A Multigroup Analysis of the Moderating role of Consumer Characteristics on E-Loyalty in the Financial Service Industry. Journal of Electronic Commerce Research, 7(2), 97-110.

Gagné, R., \& Briggs, L. J. (1974). Principles of instructional design. New York: Holton, Rinehart \& Winston.

Gamberoni, E., von Uexkull, E. \& Weber, S. (2010). The Role of Openness and Labour Market Institutions for Employment Dynamics during Economic Crises. ILO: Employment Sector Employment Working Paper No. 68.

Gilly, M. C. \& Zeithaml, V.A. (1985). The Elderly Consumer and Adoption of Technologies. Journal of Consumer Research, 12(3), 353-357.

Goldberg, L. R. (1990). An alternative Description of personality: The BigFive factor structure. Journal of Personality and Social Psychology, 59, $1216-1229$.

Goldstein, I. (1993). Training in Organizations: Needs Assessment, Development, \& Evaluation. Monterey, CA: Brooks-Cole.

Guilford, J. P. (1959). Personality. New York: McGraw Hill.

Gustafson, K. L, \& Branch, R. B. (1997). Survey of instructional development models (3rd Eds.). Syracuse, NY: ERIC Clearinghouse on Information and Technology.

Hisham, A. (2015). Human capital: A Mounting Demand in the Industry. Islamic Finance News, 1(3) 1-3.

Hofstede, G. (1980). Culture's Consequences: International differences in Work-Related Values. CA: Sage.

Holcomb, J. (1993). Make Training Worth Every Penny. Del Mar, CA: Wharton. 
Judge, T.A., Heller., D \& Mount., M.K. (2002). Five Factor Model of Personality and Job Satisfaction: A Meta-Analysis. Journal of Applied Psychology, 87, 530-541.

Kaiser, H. F. (1970). A Second Generation Little Jiffy. Psychometrika, 35, 401-415.

Kaiser, H. F. (1974). An Index of Factorial Simplicity. Psychometrika, 39, $31-$ 36.

Khan, A. (2008). Tackling the failure of microfinance efforts through amalgamating microfinance with charity: two viable alternatives in the context of Pakistan, Ustralasian Accounting, Business and Finance Journal, 2(2). Retrieved from http://ro.uow.edu.au/aabfj/vol2/iss2/.

Kirkpatrick, D. L. (1959). Techniques for evaluating training programs. Journal of the American Society of Training Directors, 13, 3-26.

Kierzkowski, A., McQuade S. Waitman, R. \& Zeisser, M. Marketing to the Digital Consumer. The McKinsey Quarterly, 33(3), 4-21.

Lussier, R.N. (2000). Leadership. USA: South-Western College.

Mager, R. F. (1962). Preparing objectives for programmed instruction. San Francisco, CA: Fearon Publishers.

McEvoy, G. M., \& Buller, P. F. (August, 1990). Five uneasy pieces in the training evaluation puzzle. Training and Development Journal, 44(8), 39-42.

McMahon, F. A., \& Carter, E. M. A. (1990). The great training robbery. New York: The Falmer Press.

Mahdi, T. M. \& Barrientos, A. (2003). Saudisation and Employment in Saudi Arabia. Career Development International, 8(2), 70-77.

Mustafa, D. \& Ibrahim, M. Y. (2013). The Emergence and Challenges of Islamic Banking and Finance in Nigeria: A Stakeholder Perception. In K.I. Dandago, A.D. Muhammad, U.A. Oseni (Eds.) Essentials of Islamic Banking and Finance in Nigeria. Nigeria, Kano: Benchmark Publishers Limited.

Nor, K. M., Sutanonpaiboon, J., \& Mastor, N. H. (2010). Malay, Chinese, and Internet Banking. Chin. Manage. Stud., 4 (2): 141-153.

Olorogun, L. A. (2013). Adopting Best Practices in the Islamic Banking Industry in Nigeria: Some case Studies. In K.I. Dandago, A.D. Muhammad, U.A. Oseni (Eds.) Essentials of Islamic Banking and Finance in Nigeria. Nigeria, Kano: Benchmark Publishers Limited.

Pierce, J. L. \& Gardner, D. G. (2002). Management and Organisational Behavior. OH: South-western/Thomson Learning. 
Phillips, J. J. (1991). Handbook of training evaluation and measurement methods. (2nd Eds.). Houston, TX: Gulf.

Raja, U., Johns, G., \& Ntalianis, F., (2004). The impact of personality on psychological contracts. Academy of Management Journal 47, 350367.

Rao, D. S. (2012). Credit Market Failures and Microfinance. International Journal of Research in Management \& Technology, 2(3), 294-297.

Robbins, S. P. (2003). Organisational Behavior (11th Eds.), New Jersey: Prentice-Hall.

Schaupp, C.L. \& Bélanger, F. (2005). A Conjoint Analysis of Online Consumer Satisfaction. International Journal of Electronic Commerce Research, 6(2), 95-111.

Sheth, J. N. \& Parvatiyar, A. (2002). Evolving Relationship Marketing into a Discipline. Journal of Relationship Marketing, 1(1), 3-16.

Slama, M. E. \& Tashlian, A. (1985). Selected Socioeconomic and Demographic Characteristics Associated with Purchasing Involvement. Journal of Marketing, 49(1), 72-82.

Salzman, J. (2000). Labour Rights, Globalization and Institutions: The Role of Organisation for Economic Cooperation and Development. Michigan Journal of International Law, 21, p. 769.

Sadi M. A., \& Al-Buraey, M. A. (2009). A framework of the implementing process: The case of Saudization. International Management Review, 5(1), $70-106$.

Senge, P. M. (1990). The Fifth Discipline: The Art and Practice of the Learning Organization. New York: Currency Doubleday.

Stevens, J. P. (2002). Applied multivariate statistics for the social sciences (4th Eds.). Hillsdale, New Jessy: Erlbaum.

Taap, A. \& Al-Awar, A. M. (July 2015). Measuring the Quality of Academic Training. Islamic Finance News, 1(2), 1-3.

Tan, V. (2017). UAE 2017 job market: Tough going. IFN Education, Vol. 3, Issue 2, 1-2, March. Retrieved 2nd April, 2017, www.IFNEducation.com.

Terberger, E. (December 2003). Microfinance institutions in the development of financial markets. CEPAL REVIEW 81, 187-202.

Watson, D., \& Clark, E. A. 1997. Extraversion and its positive emotional core. In R. Hogan, J. A. Johnson, \& S. R. Briggs (Eds.), Handbook of personality psychology (pp. 767-793). San Diego: Academic Press.

Worthington, A. \& Higgs, H. (2003) Factors explaining the choice of a Finance major: the role of student characteristics, personality and 
perceptions of the profession, Accounting Education, 12(3), 261281.

Worthen, B. R., \& Sanders, J. R. (1987). Educational evaluation. New York: Longman.

Zeithaml, V.A. (1985). The New Demographics and Market Fragmentation. Journal of Marketing, 49(3), 64-75.

Zeithaml, V.A., Berry L.L., \& Parasuraman, A. (1996). The Behavioral Consequences of Service Quality. Journal of Marketing, 60(2), 3146. 
244 Banking The Unbanked A Perceived Recipes for Poverty Eradication Program: Induction of A New Islamic Microfinance Model in Nigeria

This page is intentionally left blank 